\title{
Capital Account Liberalization and Capital Movement in China
}

\author{
Badar Alam Iqbal, Monarch University, Switzerland \\ Nida Rahman, Aligarh Muslim University, India \\ (iD https://orcid.org/0000-0002-4564-1691 \\ Mohd Nayyer Rahman, Aligarh Muslim University, India \\ (iD) https://orcid.org/0000-0001-6512-0028
}

\begin{abstract}
Capital account liberalization has always been at the core of economic policymaking. China is a country which has chosen to go gradual in opening up the capital account. The present research seeks to manoeuvre aspects of capital account liberalization for the Chinese economy. An empirical investigation is run for ascertaining the particular influence capital controls has had on foreign direct investment in China which has outpaced other capital flows in the past decades. The model applied involves foreign direct investment inflows as the dependent variable while four variables are independent. The stationarity of the univariate series is checked with the use of Augmented Dicky Fuller test. The study concludes with theoretical understanding that full liberalization of the current account in China has overall benefited the economy. The outcome of the study suggests that there is no significant bearing of current account liberalization on foreign direct inflows.
\end{abstract}

\section{KEYWORDS}

Capital Account, Capital Account Restrictions, Capital Liberalization, China, Foreign Direct Investment, Growth, Portfolio Investment, Regression

\section{INTRODUCTION}

Globalization has generated enormous gains for the developing world as is displayed in their ameliorating economic growth and wide connectivity with the developed regions of the world economy. Macro-economic data for indicators like Gross Domestic Product, Investment, Productivity, etc. entails the success of globalisation and integration into the world economy. The emerging market economies of present times are moving undeterred, and credited to the phenomenon of globalisation. More specifically, several aspects of globalisation like trade liberalization and capital flight have added to the performance of emerging market countries. The addition to global GDP by emerging market economies has over the period bloomed extravagantly. However, over time unprecedented economic events have charred the belief of globalization being a generator of gains only. The opening up of financial and international accounts of economies have been associated by many to the brewing of economic crisis and downturns in progress (Demirguc-Kunt \& Detragiache, 1998; Easterly et al., 1999; Stiglitz, 2000). Past economic misfortunes in the form of Mexican Financial Crisis of 1994, Asian Financial Crisis of 1997 and the Global Financial Crisis of 2008 had, as believed by many, in its backdrop capital controls undoing as a prominent reason. The series of economic downturns in 
the form of currency and financial crisis gave impetus to the belief of Capital Account Liberalization bringing these economic mishaps. To counter the accompaniment of economic crashes as the capital account unleashes, many countries especially the developing and emerging market economies started erecting controls on their capital account dealings. Much of the capital controls emerged out of fear of impediment-free capital movements carrying distortions with them (Sulimierska, 2008). Nevertheless, another perspective holds that limiting capital movements is itself a distortion (Eichengreen, 2001).

China's venture into the policy regarding Capital Account Liberalization (CAL) has been a restrained yet progressive one. While Foreign Direct Investment movements have witnessed an opening for the Chinese economy, Portfolio flows remain chained to a considerable extent. The reason often brought into discussion for this behaviour is the volatility concern guiding China to propel one kind of capital flow while treading cautiously in its dealing on another kind of capital. The issue of volatility characteristic of capital flows has been dealt at great length by a huge number of studies. The dominant view about the volatile character of capital flows reckons Foreign Direct Investment to be less fragile to extraneous factors while Portfolio flows stand as the more volatile one. The less volatile feature of Foreign Direct Investment and a long term source of finance has been sworn in studies led by Dadush et al., 1994; World Bank, 1999; Hausman \& Fernandez-Arias, 2000; Iqbal, Rahman \& Turay, 2017; and Rahman \& Rahman, 2018. The surge in Foreign Direct Investment flows to China has been a dominating phenomenon in the overall capital flows pouring into the economy. The period post China's embrace of market reforms in the late 1970s saw a great incoming of capital specifically taking the form of Foreign Direct Investment. Portfolio Investment remained behind hand. However, the situation over time has improved with Portfolio flows climbing modestly.

The pacing up of Portfolio flows and the turn up in Foreign Direct Investment flows has a connection with the easing in capital controls. As the Chinese economy went on relaxing rules regarding capital flows, the numbers kept on running. Major relaxations in the capital account came up in 1984 where China opened its coastal cities for the embrace of foreign capital. Figure 1 is a representation of the expansion in Foreign Direct Investment and Foreign Portfolio Investment over the period. It can be made out from the figure that the gap between Foreign Direct Investment and Total Portfolio Investment inflows is contracting in recent years. The reasons might emerge from China's furthering of liberalisation in the Portfolio category of investments too. This reverberates in figure 2 also where the gap between Foreign Direct Investment flows as a share of GDP and Portfolio Investment as a share of GDP are seen to be close to convergence in the latest years. The figure tells us that the greatest divide has been in the years following 1992. The dip in portfolio investment after 1997 corroborates with the pessimism regarding capital account liberalization post the Asian Financial Crisis, 1997.

China, as its development policy, is propelling capital account liberalisation to a greater extent and also internationalising its currency. About capital account liberalisation, China has been wary especially post the Asian Financial Crisis of 1997. However, to garner technological prowess, FDI regulations were consistently brought down since the 1980s. Thus, it fits to ask what has been the progress in capital account controls and regulations since the reform period. If there is any progress, how does it translate in influencing Foreign Direct Investment flows and Portfolio Flows? Has capital account liberalization paved the way for capital movement or has impeded it? The paper moves to answers these queries. Putting into perspective the conflicting advice on capital account liberalization, it is important to excavate the issue in the light of embroiling relevance of Foreign Direct Investment in the emerging market economies.

\section{REVIEW OF LITERATURE}

The literature on Capital Account Liberalization moves in two directions. One supports Capital Account Liberalization whereas the second heavily connotes Capital Account Liberalization to a policy that exacerbates the vulnerabilities of economies going for it and thus in a way address it as 
Figure 1. Capital movement in China since 1984. Source: Authors Compilation from World Bank Database.

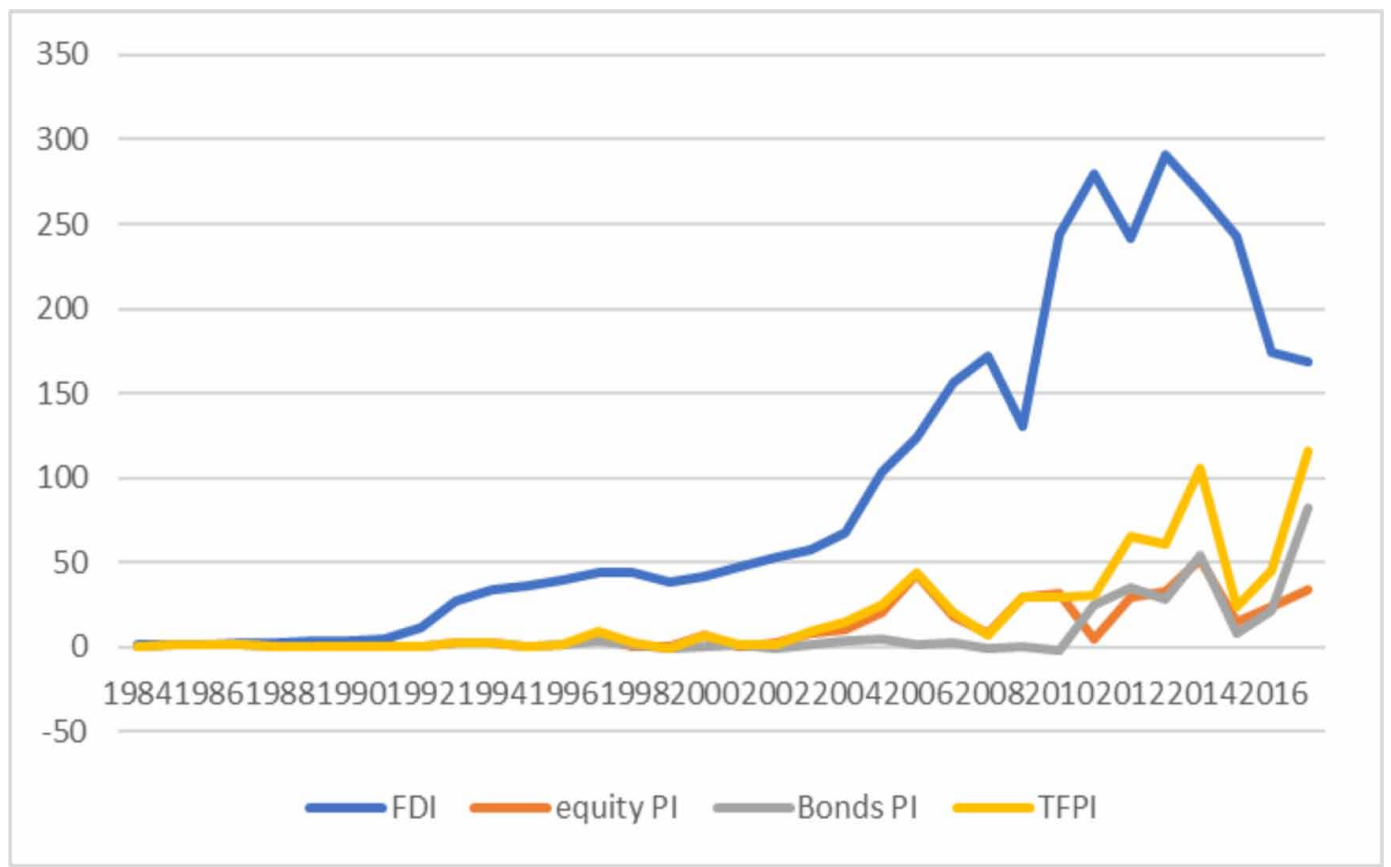

a harbinger of financial doldrums. The first approach of viewing Capital Account Liberalization as bringing benefits to economies is conditional on various characteristics of the economies in question. These conditions may encompass features representing existing macro-economic soundness. For instance, market, trade policy, domestic financial system, exchange rate management and institutions play a great part in directing the way of capital account liberalization on economies system. Given the first approach, ample evidence exists to validate the notion. This is the reason of developed and advanced countries going all for capital account liberalisation. Also, there exists a wealth of studies on discussing Capital Account Liberalization to be a growth propelling exercise. The second approach to analysing capital account liberalisation sees it through the lens of crevices in the developing economies that offsets any marginal positive effect accruing from the phenomenon. This notion is evidenced in the chaos created during the time of the Asian financial crisis of 1997 when capital was pulled off in abundance from many East Asian countries abruptly. Studying the phenomenon in this context, countries like China erected measures that restricted capital and it proved a saviour in the case of China which remained considerably unscathed from the misevent. Thus, we can call underlying empirical evidence of both approaches incapable of reaching a universal dictum on Capital Account Liberalization. The present section reviews these two approaches at length to develop an understanding of the effects emanating from the process.

Studies delivering on the contention that Capital Account Liberalization has a positive bearing on the countries accommodating it are ample in number yet are debatable in the policy sphere. In their endeavour to bring to notice the good effects of capital account opening, they have taken a route similar to that followed by neo-classical theorists. Capital is likened to any other good the trade for which is bound to be a gain for players. These studies move in establishing the benefits of capital account liberalisation conditional on the sturdiness of macro-economic setting of economies. Factors such as Inflation, exchange rate stabilization, trade liberalization, domestic financial market, rule of law, institutions carry ample weight in deriving benefits from capital account liberalization (McKinnon, 1991; Kraay, 1998; Buiter\&Taci, 2003; Henry, 2003; Gibson, Tsaveas\&Vlassopoulos, 2006;Arteta, 
Figure 2. Capital movement as a percentage of GDP in China. Source: Author's compilation from World Bank Database.

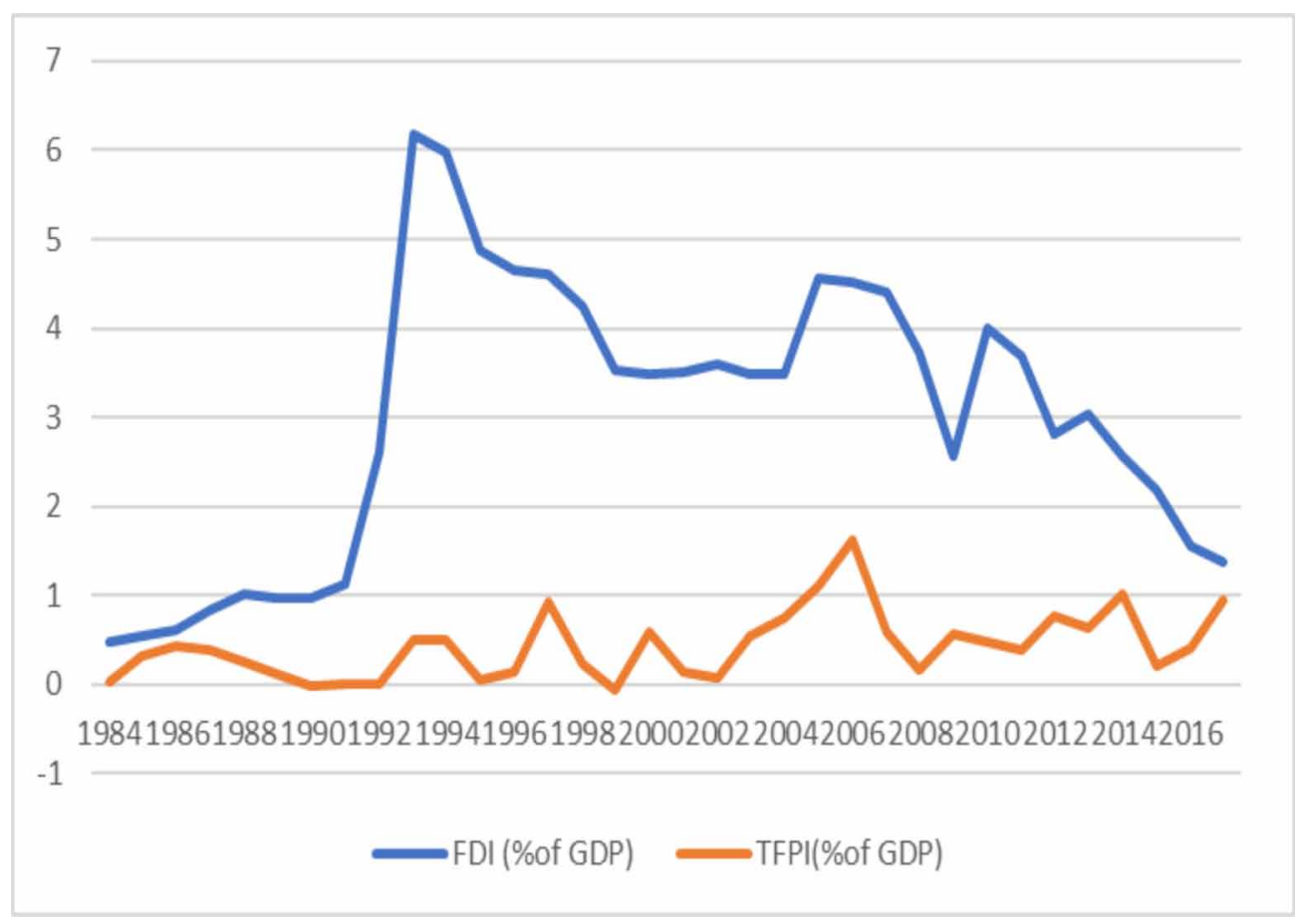

Eichengreen, \&Wyplosz, 2001 and Eichengreen, Gullapalli, \& Panizza, 2011). For many thinkers, the question demanding scrutiny was not whether to liberalize the capital account or let it remain regulated but about the pre-conditions of Capital Account Liberalization. McKinnon (1991) was of a similar opinion. His principle policy question was when to liberalize the capital account. Whether macroeconomic stabilization and reforms should follow capital account liberalization or it should be vice versa was the major notion his study was based on. Arteta, Eichengreen\&Wyplosz (2001) brought into notice the importance of macroeconomic stabilization and financial liberalization. They reckoned that in the presence of macroeconomic imbalances, capital account liberalization entails severe busts than assists. Krayy (1998) enquired the status of CAL as believed by many to be purporting growth process in advanced nations or those characterized by macro-economic stability and the presence of strong institutions. His analysis delivered results reflective of only a marginal effect on growth, inflation and investment in a cross-sectional setup. Albeit, the effect was deemed more pronounced about bringing a fall in the cost of capital, an increase in investment and productivity of workers in the context of stock market liberalization (Henry, 2003). Also, results by Eichengreen, Gullapalli\& Panizza, 2011 reinforces the belief that gains accruing from Capital Account Liberalization are confined to countries performing better on financial systems, rule of law, and accounting standards. The growth effects of Capital Account Liberalization are attended to by many studies. However, the conclusions differ markedly owing to the deflection from a single methodology adopted and their dealing with different time frames. The quantification of capital account liberalization has been a pebble in the way of getting a universal answer on the issue. A listicle of studies delving on growth prospects of Capital Account Liberalization both independent of other factors and those dependent on other channels to reach economic growth are briefed in Table 1.

The second outlook on Capital Account Liberalization attaches it to be a harbinger of financial doldrums. This view was purported mostly in the period following the East Asian Financial Crisis of 1997 that took into its swamp economies of Thailand, Malaysia, Singapore, Philippines and 
South Korea. China stood considerably unscathed from the crisis owing to its controls on short term flows. The unprecedented events of the financial crisis have a bearing on the pessimistic approach towards Capital Account Liberalization, especially that coming from the developing economies. Stiglitz (2000) attaches short term capital flows to be a creator of instability. Giving both the case for and against Capital Account Liberalization, Stiglitz reckons that capital and financial markets are entirely different from the goods market and thus it demands a debunk from applying free trade notion to capital and financial account too. In explaining the volatile feature of short term capital flows, Stiglitz brings into sight that it was these flows that brought a crisis. Angkinand et al. (2010) find the relationship between financial liberalization and the probability of a banking crisis to be taking an inverted U-shape. The result supports the view of financial liberalisation giving way to a banking crisis to spread its roots in situations of weak regulations. In the presence of adequate supervision, liberalization shreds the likelihood of a crisis. There follows the conclusion that initially liberalization might produce chances of crisis to erupt, but over the time the negatives might be offset provided governance rules and risk management skills follow suit. Scepticism for capital account liberalization is prominent in the arguments made by Rodrik (1998). Looking at 100 developed and developing countries and relating their capital account positions in liberalisation with Investment (as a share of GDP), per capita GDP growth and inflation, he finds no evidence stating that capital account liberalisation has ameliorated the economic performance. His main proposition on opening capital account is that there is a heavy difference in the way goods market operate and the manner of working of financial markets. Market failures arising from asymmetric information regarding financial markets makes the application of the free flow of capital approach untenable. However, the discussion by Rodrik and Stiglitz on the incapability of applying the goods market rule to capital and financial markets rule does not translate in the present scenario of dealings. Whether or not Capital account openness is associated with financial crashes and setbacks is empirically addressed by Ghosh, Ostry and Qureshi (2016). Addressing the question for a period of 1980-2013 for Emerging Market Economies, they find that in periods of capital account openness, capital flows have a statistically significant relationship with financial crashes. Their findings further deem capital flows dominated by FDI flows to be less likely of creating a crisis like situation. However, Erten and Ocampo found a contrasting outcome on the same issue for 51 emerging market economies for the period 1995 to 2011. They concluded that countries with relaxation in capital account regulations are more stable in their macroeconomic indicators.

Countries have approached capital account liberalisation gradually, and this has tremendously brought a change in the number of capital flows and has extensively shuffled their basket of capital flows. This is evidenced in studies by Verikios, 2018; Pasricha et al., 2018; Hatzvi, Meredith \& Nixon, 2015; Bayoumi \& Ohnsorge, 2013; Noy \& Vu, 2007; Kimball \& Xiao, 2006; and Asiedu \& Lien, 2004. Also, many studies have derived both domestic and multilateral effects of controls on capital account. Pasricha et al. (2018) analyse something similar for a group of emerging market economies. Finding the effects for 2001-2012 on a new dataset of capital controls, they find that capital control loosening had an ephemeral impinge on gross capital flows; both inflows and outflows with a negligible bearing on net capital inflows.

Verikios (2018) analysed the influence of loosening of capital controls by China on its Foreign Direct Investment and trade. Through a computable general equilibrium model, Verikios can map out the changes in Foreign Direct Investment as China braces for a partial capital account liberalization. It is seen that FDI registers an increase as capital controls are undone. It also lowers the cost of capital in China as against other regions of the world. Also, there emerges evidence of a change in the layout of capital flows in China as capital account liberalization paces. This is evidenced in an enquiry led by Hatzvi, Meredith \& Nixon (2015). Over the years of gradually unleashing capital account, China has witnessed a greater pouring of Foreign Direct Investment Flows and Banking related flows than portfolio flows. Further liberalization is believed to bring risks of a new kind of economic and financial crisis. China's capital flows tilting heavily toward Foreign Direct Investment is reverberated in a study 
done by Kimball \& Xiao (2006). A similar, however less impactful result was delivered by Noy \& $\mathrm{Vu}$ (2007). A panel data study for the period 1984-2000 delivers results of capital account openness positively affecting FDI flows. However, the effect is meagre. Other factors accounting for varied characteristics of economies are found to be having a more pronounced impact on FDI flows. Asiedu $\&$ Lien while searching for results of capital controls on FDI in the case of 75 developing countries reach the juncture that capital controls are a deterrence to FDI flows. Resting their judgement on the impact Capital Account Liberalization brings to Portfolio Investment, Bayoumi \& Ohnsorge (2013) brings relevant details into sight. It finds that as capital control reduce, cross-border portfolio flows are dampened both for the source as well as destination countries. Looking at the varied results delivered by different studies, a universal outlook is difficult to reach. The underlying structures of developed and developing countries bring a deflection in effects arising from any policy. China has over the years registered strides in the opening of capital account. Even portfolio flows have gained movement to and from China. The importance that Capital Account Liberalisation and Exchange Rates have in stabilising an economy makes it imperative to be studied indulgently.

\section{CONCEPTUAL FRAMEWORK}

\section{Capital Account}

The Balance of Payments Manual edition 6 defines Capital Account as one showing a) capital transfers receivable and payable between residents and non-residents and $b$ ) the acquisition and disposal of non-produced, non-financial assets between residents and non-residents. The IMF in its BPM-6 demarcates between Capital Account and Financial account, the latter involving transactions of financial nature between residents and non-residents. It is important to note that economic literature usually uses capital account and financial account interchangeably. The financial account stores all dealings in financial assets and liabilities generating from the transactions between residents and non-residents of goods, services, income, capital account, financial account etc. Thus, entries relating to direct investment, portfolio investment, Other investment, financial derivatives etc. form a constituent of the capital account.

\section{Foreign Direct Investment}

The OECD in its $4^{\text {th }}$ edition of Benchmark Definition of Foreign Direct Investment defines FDI to be "the category of international investment that reflects the objective of a resident entity in one economy to obtain a lasting interest in an enterprise resident in another economy".

\section{Portfolio Investment}

The BPM-6 of IMF defines portfolio investment as "cross-border transactions and positions involving equity or debt securities other than those included in direct investment or reserve assets".

\section{Other Investments}

Paragraph 6.61 of the BPM-6 talks about other investments as a 'residual category'. It engulfs "transactions other than those included in direct investment, portfolio investment, financial derivatives, employee stock options and reserve assets".

\section{Capital Account Liberalization}

Henry (2007) describes Capital Account Liberalization as "a decision by a country's government to move from a closed capital account regime, where capital may not move freely in and out of the country, to an open capital account system in which capital can enter and leave at will'. In a nutshell, capital account liberalization means freeing capital movements from controls and restrictions. 
Table 1. Studies linking Capital Account Liberalization (CAL) and growth

\begin{tabular}{|c|c|c|c|c|}
\hline S. No. & Author & Time Frame & Estimation Technique & Finding \\
\hline 1. & $\begin{array}{l}\text { Grilli\&Milesi-Ferretti } \\
\text { (1995) }\end{array}$ & 1960-1989 & Logit Regression & $\begin{array}{l}\text { No effect of an open } \\
\text { Capital Account on } \\
\text { Growth }\end{array}$ \\
\hline 2. & Klein \&Olivei (2008) & $1986-1995$ & Growth regression & $\begin{array}{l}\text { Capital Account Opening } \\
\text { promotes growth through } \\
\text { financial depth channel }\end{array}$ \\
\hline 3. & Quinn (1977) & 1950-1979 & Regression & $\begin{array}{l}\text { Capital Account opening } \\
\text { promotes growth }\end{array}$ \\
\hline 4. & $\begin{array}{l}\text { Quinn, Iclan\& Toyoda } \\
\text { (2001) }\end{array}$ & 1960-1995 & Fixed Effects Panel Model & $\begin{array}{l}\text { CAL has a robust } \\
\text { and direct effect on } \\
\text { economic growth in } \\
\text { most economies. For } \\
\text { Emerging market } \\
\text { economies with weak } \\
\text { welfare systems, CAL } \\
\text { does not bring higher } \\
\text { growth }\end{array}$ \\
\hline 5. & Arteta et al. (2001) & $1980-89$ & OLS regressions & $\begin{array}{l}\text { Limited evidence } \\
\text { of positive growth } \\
\text { effect when CAL is } \\
\text { conditioned on law and } \\
\text { order }\end{array}$ \\
\hline 6. & Michael W. Klein (2005) & 1976-1995 & Neo-classical growth model & $\begin{array}{l}\text { Capital Account opening } \\
\text { has a significant effect } \\
\text { on economic growth }\end{array}$ \\
\hline 7. & Edison et al. (2004) & - & - & $\begin{array}{c}\text { No impact of CAL } \\
\text { on growth even after } \\
\text { controlling for financial } \\
\text { development }\end{array}$ \\
\hline 8. & Honig (2008) & $1970-2005$ & OLS Regression, IV estimates & $\begin{array}{l}\text { CAL has a significantly } \\
\text { positive effect on growth }\end{array}$ \\
\hline 9. & Hichem\&Alaoui (2010) & $1984-2007$ & Dynamic Panel Model & $\begin{array}{l}\text { Direct correlation amid } \\
\text { CAL and economic } \\
\text { growth }\end{array}$ \\
\hline 10. & Rodrik (1998) & - & Growth Regression model & $\begin{array}{l}\text { No effect on Growth } \\
\text { independent of the } \\
\text { financial quality }\end{array}$ \\
\hline
\end{tabular}

Source: Prepared by Authors

\section{CHINA'S VENTURE IN CAPITAL ACCOUNT LIBERALIZATION- TRENDS}

China's venture in liberalizing its capital account has been a gradual and cautiously approached step. Since 1978 when China embraced market reforms, Capital Account has been approached with great watchfulness. The integration of China in the world economy made it open its capital account in steps. Before the market reforms of 1978, penetration of capital flows in various forms was meagre. For example, the decade of the 1970s and 80s recorded limited capital influx. A major transition in the capital account was witnessed in the form of liberalising restrictions for Foreign Direct Investment flows in the 1990s. However, the motivation for this step was China's requirement of technology and prowess. This is the main reason for a deflection between FDI and other forms of capital flowing into China since the start. Other flows of capital have not scored high relative to the position Foreign 
Direct Investment has taken. This was because of the incentives given to foreign investors on FDI than on other capital flows. Portfolio investment was severely tamed and it is reflected in the minuscule amounts it has taken in comparison to FDI in the whole decade of the 90s (Figure 1). However, with China's development agenda to fully open the capital account by 2020 and consistent changes in capital account controls, there has been a modest stride in Portfolio investment as well. The International Monetary Fund's Exchange Arrangements and Restrictions Annual Manual publish information on capital controls about each year. A chronological description of the changes in Capital Account restrictions has been made from the information provided by the manual. It is partly taken from Prasad \& Wei (2005) and partly organised by the author. Information from 1980 to 2005 is taken from chronology narrated by Prasad \& Wei (2005). Information from 2006 to 2010 is not openly published by the IMF. Hence, information regarding 2011 to 2016 is taken, provided by the IMF.

It is evident from Table 2 and 3 that China has come a long way in opening the capital account. However, a lot remains which is expected to be delivered in the coming years. For example, it can be seen from regulations eased on certain capital inflows and outflows where China has moved from approval requirement to the reporting system. The reporting system is considered comparatively hassle-free and less time consuming than requiring approval from several state or government bodies. The major revamp in China's capital account policy was witnessed in 1984 when a larger part was opened up for overseas investors and firms. China's effort in bestowing upon 14 of its coastal cities the status of economic and technology zones to lure foreign investment acted a catalyst in the boom of Foreign Direct Investment Inflows in the early 1990s. This boom sustained a great length of time for China. Further years of liberalization witnessed a modest reinstating of portfolio investment rules and regulations. In an attempt to reach its goal of internationalization of Renminbi, China has stepped up its reforms in the securities and bond market. In the context of the world economy, there has been a considerable improvement in capital account easing. The trend of improvement is observed in the total number of measures spiralling upwards. Figure 3 reports this trend for the total number of measures being reported for all 186 IMF member countries. A demarcation in the measures telling the easing of capital account and tightening of the capital account is pictured in Figure 4. It can be declared from the figures that there is a lot more easing than restricting in the capital account for the periods 2011-2016; period reflecting post-global financial crisis. Albeit, the tightening measures still pose a potential for liberalization by IMF member countries.

Figure 4 shows that measures relating to easing capital account are more pronounced than the tightening measures adopted by China in its various classifications. The policy of internationalization of Renminbi and moving to full capital liberalization is expected to entail further easing measures in the coming years.

\section{IMPACT OF CAPITAL ACCOUNT LIBERALIZATION ON CAPITAL FLOWS IN CHINA}

This section of the paper tries to test for the specific impact that Capital Account Liberalization poses on capital flows into China. Two kinds of capital flows make up for the investigation part in our analysis; Foreign Direct Investment Inflows and Portfolio Investment Inflows. A dummy variable is created that stands to mark the presence or absence of Capital Account Liberalization (CAL) for the period 1984-2016. All the years that have registered a liberalization in regulations regarding capital account transactions take the value 1 and all other years in which no changes were made in the capital account take the value of 0 . Several control variables that form a part of independent variables in the model are drawn from the literature. Indicators like market size, infrastructure, and trade openness are deemed important in the literature for determining capital flows in the host countries. Hasan, Rahman \& Iqbal (2017) supposes economic size, trade openness, exchange rate mechanism, inflation etc. as the potential determinants of FDI. For this reason, GDP per capita, mobile subscriptions per 100 
Table 2. Changes in Capital Account Restrictions (1980-2005)

\begin{tabular}{|c|c|c|}
\hline S. No. & Period & Changes in Capital Account Restrictions \\
\hline 1. & 1980 & $\begin{array}{l}\bullet \text { Foreign Borrowing approved } \\
\text { - Foreign Investment projects subject to the permission of the Foreign Investment Control Commission } \\
\bullet 33 \text { per cent tax on profits of JV } \\
\bullet \text { An additional tax of } 10 \text { per cent on remitted profits }\end{array}$ \\
\hline 2. & 1981 & $\bullet$ No Changes \\
\hline 3. & 1982 & $\begin{array}{l}\bullet \text { Law on Income Tax for Foreign Enterprises came into being } \\
\text { - Bank of China decided to grant (i) foreign currency loans, (ii) finance export services for foreign } \\
\text { projects }\end{array}$ \\
\hline 4. & 1983 & $\begin{array}{c}\text { - Foreign firms' tax on income earned from interest on loans, agriculture, communications, energy } \\
\text { development, education, transport \& scientific research for the time } 1983-85 \text { slashed by } 50 \text { per cent } \\
\text { - Tax law for joint ventures was approved a change } \\
\text { - New rules for JV was set about exchange controls }\end{array}$ \\
\hline 5. & 1984 & $\begin{array}{l}\text { - Shanghai to permit foreign investment projects to a value of up to US\$ } 10 \text { million } \\
\text { - Fourteen coastal cities were proclaimed to be opened up for FDI flows under which } 10 \text { per cent tax on } \\
\text { profits remitted would be waived off, investors investing in these zones would be waived customs, industrial } \\
\text { and commercial tax. Entities under this would be exempt from export duties as well } \\
\text { - JVs operating in the } 14 \text { coastal cities opened up for the overseas world would be subjected to } 15 \text { per } \\
\text { cent income tax on the permission of Ministry of Finance rather than the } 33 \text { per cent established in the } \\
\text { previous periods } \\
\text { - Beihai nominated as an economic and technological development zone under which preferential tax } \\
\text { rates similar to other SEZs will be applied } \\
\text { - Shanghai announced a preferential tax exemption under in congruence with that applied in Shenzen } \\
\text { economic zones } \\
\text { - In FDI investment projects, income tax was brought down to } 15 \text { per cent provided the project } \\
\text { undertakes advanced technology or the amount invested be beyond US } \$ 30 \text { million }\end{array}$ \\
\hline 6. & 1985 & $\begin{array}{l}\text { • Rules driving the establishment of foreign JVs in Shanghai were loosened } \\
\text { - Nine provinces and one autonomous region were announced to open for foreign firms activities of } \\
\text { exploration and establishment of oil and gas reserves } \\
\text { • Foreign banks setting up branches in China's SEZ were regulated }\end{array}$ \\
\hline 7. & 1986 & $\bullet$ No Changes \\
\hline 8. & 1987 & $\begin{array}{l}\text { - Provisional regulations approved permitting financial institutions and enterprises with sources of } \\
\text { foreign exchange income to guarantee foreign exchange obligations of other debtors }\end{array}$ \\
\hline 9. & 1988 & $\bullet$ A new law on Chinese foreign cooperative JVs \\
\hline 10. & 1989 & $\begin{array}{l}\text { - All commercial borrowing from foreign sources to be only permitted through the People's Bank of } \\
\text { China } \\
\text { - Short term debt to not reach beyond } 20 \text { per cent of the entire debt held by the entity } \\
\text { - Outbound direct investment to be done only after approval from China's government and SAEC }\end{array}$ \\
\hline 11. & 1990 & $\begin{array}{l}\text { - Relaxed rules on FDI (management rights of foreign investors, simplification of approval procedure of } \\
\text { investment projects) } \\
\text { - Plans for developing Pudong new area where to promote foreign capital inflow foreign investors would } \\
\text { be given incentives to invest in infrastructure and bank establishments } \\
\text { - Offered land use rights for a maximum of } 40 \text { years for commercial, tourism and recreational motive } \\
\text { and } 70 \text { years for residential motives }\end{array}$ \\
\hline 12. & 1991 & $\begin{array}{c}\text { - Income Tax law for foreign-funded enterprises and fully owned foreign enterprises embraced calling } \\
\text { for cancelling the } 10 \text { per cent tax levied on remitted profits } \\
\text { - Regulations on borrowing overseas of commercial loans by residential institutions and Rules on } \\
\text { Foreign Exchange Guarantee by Resident Institutions in China issued }\end{array}$ \\
\hline 13. & 1992 & • Further liberalisation of Trade and Investment entailing opening up of more regions \\
\hline 14. & 1993 & $\bullet$ No Changes \\
\hline 15. & 1994 & - No Changes \\
\hline 16. & 1995 & - No Changes \\
\hline 17. & 1996 & - Regulation on External Guarantees provided by domestic entities passed \\
\hline 18. & 1997 & No Changes \\
\hline 19. & 1998 & $\begin{array}{l}\bullet \text { By-laws on the regulation of external guarantees by domestic institutions issued } \\
\text { - Line of credit maturing between } 90 \text { days and a year deemed as short term credit. Those extending } \\
\text { beyond a year termed as medium or long term credit } \\
\bullet \text { Regulations on bond issuance issued } \\
\bullet \text { Changes in external borrowing laws }\end{array}$ \\
\hline 20. & 1999 & $\bullet$ Renminbi loans relaxed \\
\hline 21. & 2000 & $\bullet$ No Changes \\
\hline 22. & 2001 & $\begin{array}{l}\text { - Chinese investors permitted to purchase B shares with either existing foreign currency deposits or } \\
\text { newly created } \\
\text { - Controls on credit operations relatively relaxed like on foreign exchange purchase for paying back loans } \\
\text { - Direct investment liberalized by allowing investment in strategic projects abroad by purchasing foreign } \\
\text { exchange }\end{array}$ \\
\hline 23. & 2002 & $\begin{array}{l}\text { - Further relaxing of controls on capital and money markets. It provided the QFIIs to be able to invest in } \\
\text { the country in A share } \\
\text { - In the area of FDI, a classification criterion was put in place. Under the criteria, FDI took place in } \\
\text { either of four categories viz., encouraged, permitted, restricted and banned. Under the classification criteria, } \\
\text { several sectors were heavily opened up for FDI }\end{array}$ \\
\hline 24. & 2003 & $\begin{array}{c}\text { - Restrictions on foreign exchange borrowing from domestic financial institutions were drastically pulled } \\
\text { down } \\
\bullet \text { Outbound investment ceiling was raised for some regions }\end{array}$ \\
\hline 25. & 2004 & $\begin{array}{l}\text { • Provisions related to QFII on buying A shares domestically was further liberalized } \\
\text { - Pre-conditions for Hong-Kong SAR banks to open branches in mainland China were heavily slashed } \\
\text { - Capital remitted through FDI can only be converted to RMB upon proof of domestic payment order }\end{array}$ \\
\hline 26. & 2005 & $\begin{array}{c}\text { - A single reserve requirement of } 3 \text { per cent was applied for both dealing in foreign currencies and } \\
\text { domestic currency }\end{array}$ \\
\hline
\end{tabular}

Source: Prepared by the Authors from Prasad \& Wei (2005) 
Table 3. Change in Capital Account Restrictions (2011-2016)

\begin{tabular}{|c|c|c|}
\hline S.No. & Period & Changes in CAL Restrictions \\
\hline 1. & 2011 & $\begin{array}{c}\text { - Controls on capital and money market were eased considerably } \\
\text { - QFIIs were permitted to invest in domestic securities in renminbi } \\
\text { - In FDI, renminbi acquired from abroad was permitted to be used for } \\
\text { investing }\end{array}$ \\
\hline 2. & 2012 & $\begin{array}{c}\text { - QFIIs was advanced to include Hong Kong subsidiaries of Chinese } \\
\text { banks, insurers permitting them to invest in domestic securities using renminbi } \\
\text { proceeds raised in Hong Kong SAR } \\
\text { - In liquidation of FDI, China slashed the approval required for the transfer } \\
\text { of proceeds to abroad } \\
\text { - In real estate transactions, China slashed foreign currency approval } \\
\text { procedures in outflows of proceeds from the selling of real estate by non- } \\
\text { residents }\end{array}$ \\
\hline 3. & 2013 & $\begin{array}{l}\text { - China further extended its QFII program by permitting FIIs from Taiwan } \\
\text { province of China, UK, Singapore to invest in domestic securities using } \\
\text { renminbi proceeds raised overseas } \\
\text { - Renminbi QFIIs can invest in a greater set of financial instruments and } \\
\text { also on stock exchange } \\
\text { - China raised the ceiling for QFIIs to US\$ } 150 \text { billion to boost inflows }\end{array}$ \\
\hline 4. & 2014 & $\begin{array}{l}\text { - Renminbi funds raised overseas were permitted to be utilized for debt } \\
\text { servicing } \\
\text { - China permitted marketing of some investment funds in Hong Kong SAR } \\
\text { - Limits on the composition of investment portfolios were eliminated } \\
\text { for qualified domestic financial institutional investors overseas renminbi } \\
\text { investments } \\
\text { - Foreign exchange capital was permitted to be converted to renminbi by } \\
\text { foreign-owned enterprises } \\
\text { - Outbound direct investments no longer require approval. China replaced it } \\
\text { with a reporting system }\end{array}$ \\
\hline 5. & 2015 & $\begin{array}{l}\text { - China eased non-residents access to interbank market transactions (bond } \\
\text { cashing, repos, loans, forwards, interest rate swaps, forward rate agreements) } \\
\text { - There was a stop in approving any more quotas for overseas investments } \\
\text { by residents } \\
\text { - Suspended approval of new QFII } \\
\text { - China allowed foreign financial institutions to take part in China's } \\
\text { interbank foreign exchange market } \\
\text { - No changes in FDI restrictions as against the previous year }\end{array}$ \\
\hline 6. & 2016 & $\begin{array}{l}\text { - QFII were allowed to remit invested principle. The period of holding it } \\
\text { was brought down from } 1 \text { year to } 3 \text { months } \\
\text { - China eased both inflow and outflow of capital overseas first in four } \\
\text { special zones then to the rest of the region as well }\end{array}$ \\
\hline
\end{tabular}

Source: Prepared by the Authors from information stated in AREAER, IMF various issues

person and export plus import as a percentage of GDP (Trade ratio to GDP) are counted as control variables in the model. Data for these variables is drawn from World Bank Database.

Our OLS regression model takes the following mathematical form;

$$
\begin{aligned}
& \text { FDII } \\
& \text { rate }+\mu
\end{aligned}=\beta_{1}+\beta_{2} \text { D_CAL }+\beta_{3} \text { GDP_percapita }+\beta_{4} \text { mobile_subscriptions }+\beta_{5} \text { Trade_ratio }+\beta_{6} \text { Exc } \_ \text {. }
$$

Where FDI Inflows is the regressand. $\mathrm{B}_{2}, \beta_{3}, \beta_{4}$ and $\beta_{5}$ are the coefficients of regressors like dummy of Capital Account Liberalization, GDP per capita, mobile subscriptions per 100 person and 
Figure 3. Total No. of Capital Control Measures by IMF members. Source: Prepared by the authors.

\section{Measures}

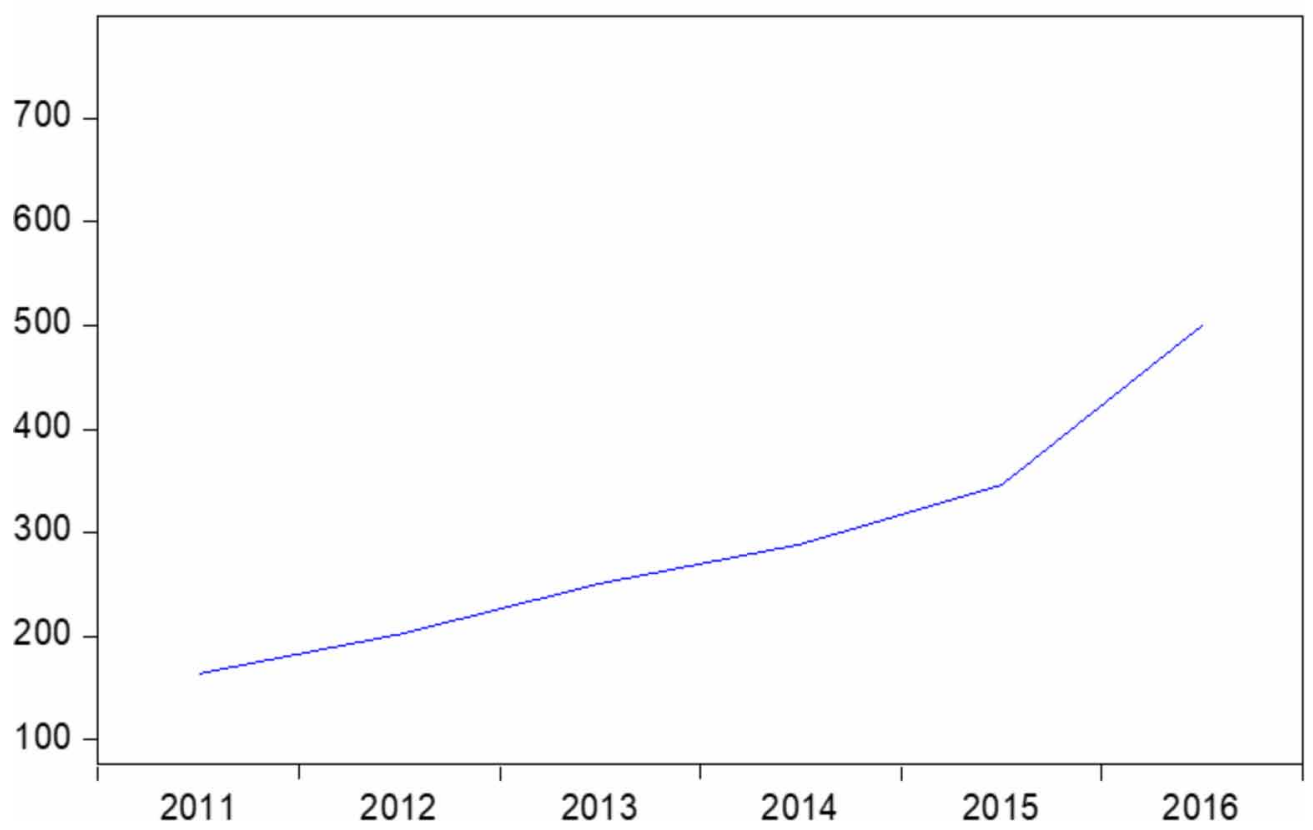

Figure 4. Type of Capital Control Measures. Source: Prepared by the authors.

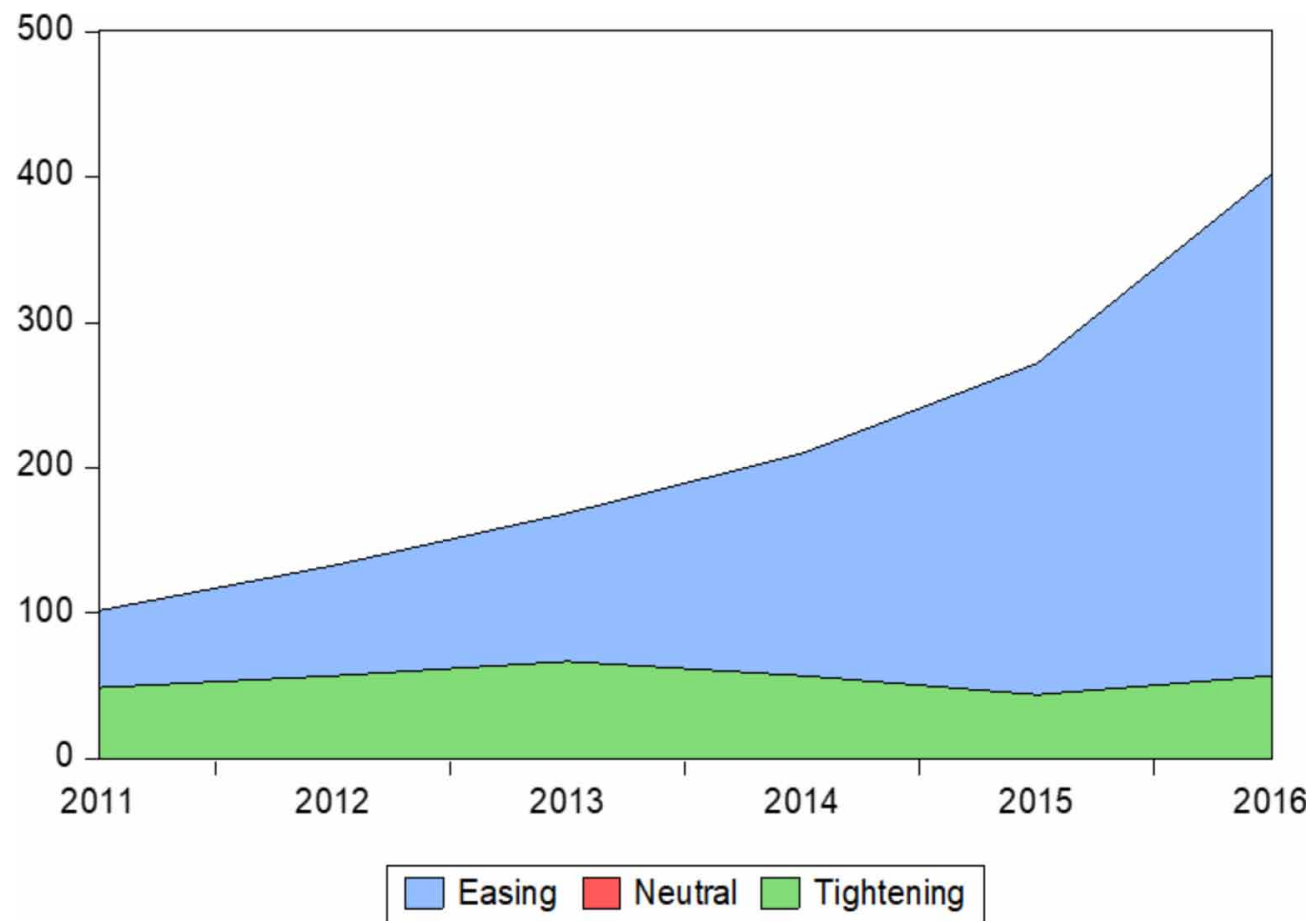


trade ratio to GDP. $\mu$ is the stochastic disturbance term that encompasses all the variables that would influence our dependant variable but are not included in the present model.

As the pre-requisite for any time series analysis to move ahead, stationarity checks are done on the data for all variables. The purpose of this preliminary exercise is to make the mean and variance of underlying variables constant i.e. make the series stationary if it does not happen to be so at levels. Augmented Dickey Fuller Tests is run on the series individually. The results for the same are reported in Table 4.It tells that only the series for GDP per capita and Exchange rates is stationary at levels. All other series are deemed to be having unit root.

Series other than exchange rate and GDP per capita become stationary after first differencing. Further to ascertain whether the choice of our variables is appropriate for the model, i.e. whether they can account independently for their influence on the dependent variable, we run a multicollinearity check. The results for the same are stated in Table 5.

It can be said from the correlation matrix generated in Table 5 that none of the independent variables is severely correlated with each other. Thus, we can rely on the independent variables included in the model for being independent in having an impetus over the dependent variable which is Foreign Direct Investment Inflows. Table 6 displays the results of OLS regression run on the variables.

Regression results in Table 6 report that none of the regressors except mobile subscriptions per 100 persons are significant in explaining Foreign Direct Investment Inflows. Current Account Liberalization is insignificant in explaining FDI movement at 5 per cent level of significance. Among the control variables, trade ratio to GDP is significant at 10 per cent level of significance. The $\mathrm{R}$-square of the model is 0.29 meaning that 29 per cent of the variations in the dependent variable can be explained by the complete model.

Table 4. Augmented Dickey-Fuller test results

\begin{tabular}{|c|c|c|}
\hline Series & p-value & Result \\
\hline FDII & 0.0001 & Stationary at first difference \\
\hline GDP per capita & 0.0075 & Stationary at level \\
\hline Mobile subscriptions & 0.0066 & Stationary at first difference \\
\hline Trade ratio to GDP & 0.0063 & Stationary at first difference \\
\hline Exchange rate & 0.0089 & Stationary at level \\
\hline
\end{tabular}

Source: Output generated by E-Views 10

Table 5. Correlation Matrix for regressors

\begin{tabular}{|l|c|c|c|c|c|}
\hline & FDII & GDP per capita & $\begin{array}{c}\text { Mobile } \\
\text { Subscriptions }\end{array}$ & $\begin{array}{c}\text { Trade Ratio to } \\
\text { GDP }\end{array}$ & Exchange Rate \\
\hline F D I I & 1 & -0.15 & 0.24 & 0.39 & -0.24 \\
\hline GDP per capita & -0.15 & 1 & 0.60 & -0.39 & 0.32 \\
\hline $\begin{array}{l}\text { M o b i 1 e } \\
\text { Subscriptions }\end{array}$ & 0.24 & 0.60 & 1 & -0.14 & -0.06 \\
\hline $\begin{array}{l}\text { Trade Ratio } \\
\text { t o G D P }\end{array}$ & 0.39 & -0.39 & -0.14 & 1 & -0.27 \\
\hline Exchange Rate & -0.24 & 0.32 & -0.06 & -0.27 & 1 \\
\hline
\end{tabular}

Source: Output generated by E-Views 10 
Table 6. OLS Regression Output (FDII as the dependent variable)

\begin{tabular}{|c|c|c|c|}
\hline Variable & Coefficient & t-statistic & Prob. Value \\
\hline CAL & $\mathbf{0 . 5 8}$ & $\mathbf{0 . 0 4}$ & $\mathbf{0 . 9 6}$ \\
\hline Mobile subscriptions & 4.49 & 2.02 & 0.05 \\
\hline GDP per capita & -0.003 & -1.20 & 0.23 \\
\hline Trade Ratio to GDP & 2.29 & 1.84 & 0.07 \\
\hline Exchange Rate & -0.03 & -0.11 & 0.90 \\
\hline \multicolumn{2}{|c|}{ R-squared } & 0.29 \\
\hline \multicolumn{2}{|c|}{ Adjusted R-squared } & 0.16 \\
\hline \multicolumn{2}{|c|}{ Durbin-Watson Statistic }
\end{tabular}

Source: Output generated by E-Views 10

\section{CONCLUSION}

China has moved considerably ahead in liberalizing its capital account. As is believed by economists and economic institutions, for the capital account to be fully liberalized, opening the current account forms a pre-setting. China has already achieved full current account openness. The paper has shown the step wise strategy of China to open its Capital Account. Measures for Internationalization of Renminbi have also accentuated with time. It has been widely acknowledged that there has been a digress in the composition of capital flows into China. While FDI takes the prominent space, Portfolio investment or short-term flows are seen behind hand. A reason behind this pattern is the nature of short-term flows to be more volatile and to generate a capital reversal abruptly. This has been proved in the scenarios of the Asian Financial Crisis. Our empirical exercise to see the impact that Capital Account Liberalization has on Foreign Direct Investment Inflows is in the light of this disparity in capital flows between various kinds in China. After looking at the results delivered by OLS regression, we cannot find a significant bearing of Capital Account Liberalization on Foreign Direct Investment Inflows in China. However, variable accounting for infrastructure and Trade openness is found to have a significant impact on Foreign Direct Investment Inflows. 


\section{REFERENCES}

Arteta, C., Eichengreen, B., \&Wyplosz, C. (2001). When does capital account liberalization help more than it hurts? (No. w8414). National Bureau of Economic Research.

Angkinand, A. P., Sawangngoenyuang, W., \& Wihlborg, C. (2010). Financial liberalization and banking crises: A cross-country analysis. International Review of Finance, 10(2), 263-292. doi:10.1111/j.1468-2443.2010.01114.x

Asiedu, E., \& Lien, D. (2004). Capital controls and foreign direct investment. World Development, 32(3), 479-490. doi:10.1016/j.worlddev.2003.06.016

Bayoumi, M. T., \& Ohnsorge, F. (2013). Do inflows or outflows dominate? Global implications of capital account liberalization in China (No. 13-189). International Monetary Fund.

Buiter, W., \&Taci, A. (2003). Capital account liberalization and financial sector development in transition countries. Capital Liberalization in Transition Countries: Lessons from the Past and for the Future, 105-141.

Dadush, U., Dhareshwar, A., \& Johannes, R. (1994). Are private capital flows to developing countries sustainable? (No. 1397). The World Bank. Retrieved https://ideas.repec.org/p/wbk/wbrwps/1397.html

Demirguc-Kunt, A., \& Detragiache, E. (1998). Financial liberalization and Financial Fragility. Proceedings of Annual Bank Conference on Development Economics.

Easterly, W., Islam, R., \& Stiglitz, J. E. (1999). Shaken and stirred: volatility and macroeconomic paradigms for rich and poor countries. Given as Michael Bruno Memorial Lecture, International Economics Association World Congress, Buenos Aires.

Edison, H. J., Klein, M. W., Ricci, L. A., \& Sløk, T. (2004). Capital account liberalization and economic performance: Survey and synthesis. International Monetary Fund Staff Papers, 51(2), 220-256.

Eichengreen, B. (2001). Capital Account Liberalization: What Do Cross-Country Studies Tell Us? The World Bank Economic Review, 15(3), 341-365. doi:10.1093/wber/15.3.341

Eichengreen, B., Gullapalli, R., \& Panizza, U. (2011). Capital account liberalization, financial development and industry growth: A synthetic view. Journal of International Money and Finance, 30(6), 1090-1106. doi:10.1016/j. jimonfin.2011.06.007

Erten, B., \& Ocampo, J. A. (2017). Macroeconomic effects of capital account regulations. IMF Economic Review, 65(2), 193-240. doi:10.1057/s41308-016-0013-1

Gibson, H. D., Tsaveas, N. T., \& Vlassopoulos, T. (2006). Capital flows, capital account liberalisation and Mediterranean countries (No. 33). Bank of Greece.

Ghosh, A. R., Ostry, J. D., \& Qureshi, M. (2016). When do Capital Inflows Surges end in Tears? The American Economic Review, 106(5), 581-585. doi:10.1257/aer.p20161015

Grilli, V., \& Milesi-Ferretti, G. M. (1995). Economic effects and structural determinants of capital controls. Staff Papers, 42(3), 517-551. doi:10.2307/3867531

Hasan, M., Rahman, M. N., \& Iqbal, B. A. (2017). Corruption and FDI Inflows: Evidence from India and China. Mediterranean Journal of Social Sciences, 8(4-1), 173-182.

Hatzvi, E., Meredith, J., \& Nixon, W. (2015). Chinese capital flows and capital account liberalisation. RBA Bulletin, (December), 39-48.

Hausmann, R., \& Fernandez-Arias, E. (2000). Foreign direct investment: good cholesterol? Presented in Seminar of Inter-American Development Bank and Inter-American Investment Corporation.

Henry, P. B. (2003). Capital-account liberalization, the cost of capital, and economic growth. The American Economic Review, 93(2), 91-96. doi:10.1257/000282803321946868

Henry, P. B. (2007). Capital account liberalization: Theory, evidence, and speculation. Journal of Economic Literature, 45(4), 887-935. doi:10.1257/jel.45.4.887 
Hichem, S., \& Alaoui, C. (2010). Capital Account Liberalization and Economic Growth: GMM Systems Analysis. International Journal of Economics and Finance, 2(5), 122-131.

Honig, A. (2008). Addressing causality in the effect of capital account liberalization on growth. Journal of Macroeconomics, 30(4), 1602-1616. doi:10.1016/j.jmacro.2008.03.003

International Monetary Fund. (2013). Balance of Payments and the International Investment Position (6th ed.). IMF.

International Monetary Fund. (2012). Annual Report on Exchange Arrangements and Exchange Restrictions. IMF. International Monetary Fund. (2013). Annual Report on Exchange Arrangements and Exchange Restrictions. IMF. International Monetary Fund. (2014). Annual Report on Exchange Arrangements and Exchange Restrictions. IMF. International Monetary Fund. (2015). Annual Report on Exchange Arrangements and Exchange Restrictions. IMF. International Monetary Fund. (2016). Annual Report on Exchange Arrangements and Exchange Restrictions. IMF. International Monetary Fund. (2017). Annual Report on Exchange Arrangements and Exchange Restrictions. IMF.

Iqbal, B. A., Rahman, M. N., \& Turay, A. (2017). Indo-US Bilateral FDI and Current Account Balance: Developing Causal Relationship. Academic Journal of Interdisciplinary Studies, 6(1), 129-139. doi:10.5901/ ajis.2017.v6n1p129

Kimball, D., \& Xiao, F. (2006, June). Effectiveness and effects of China's capital controls. In Conference: WTO, China, and the Asian Economies, IV: Economic Integration and Economic Development, University of International Business and Economics, Beijing, China, June (pp. 24-25). Academic Press.

Klein, M. W. (2005). Capital account liberalization, institutional quality and economic growth: theory and evidence (No. w11112). National Bureau of Economic Research.

Klein, M. W., \& Olivei, G. P. (2008). Capital account liberalization, financial depth, and economic growth. Journal of International Money and Finance, 27(6), 861-875. doi:10.1016/j.jimonfin.2008.05.002

Kraay, A. (1998). In search of the Macroeconomic effects of the Capital Account Liberalization. https://faculty. fuqua.duke.edu/ charvey/Spur/Kraay_In_search_of.pdf

McKinnon. (1991). Ronald I. The Order of Economic Liberalization. Johns Hopkins University Press.

Noy, I., \& Vu, T. B. (2007). Capital account liberalization and foreign direct investment. The North American Journal of Economics and Finance, 18(2), 175-194. doi:10.1016/j.najef.2007.04.001

OECD. (2008). OECD Benchmark Definition of Foreign Direct Investment (4 ${ }^{\text {th }}$ ed.). Retrieved http://www.oecd. org/daf/inv/investmentstatisticsandanalysis/40193734.pdf

Pasricha, G. K., Falagiarda, M., Bijsterbosch, M., \& Aizenman, J. (2018). Domestic and multilateral effects of capital controls in emerging markets. Journal of International Economics, 115, 48-58. doi:10.1016/j. jinteco.2018.08.005

Prasad, E., \& Wei, S. J. (2005). The Chinese approach to capital inflows: patterns and possible explanations (No. w11306). National Bureau of Economic Research.

Quinn, D. (1997). The correlates of change in international financial regulation. The American Political Science Review, 91(3), 531-551. doi:10.2307/2952073

Quinn, D. P., Inclan, C., \& Toyoda, A. M. (2001). How and where capital account liberalization leads to economic growth (Unpublished manuscript). Georgetown University.

Rahman, N., \& Nayyer, R. M. (2018). Do Foreign Direct Investment Inflows Impinge Gross Domestic Product? A Venture Out for ASEAN. Jurnal Ekonomi dan Studi Pembangunan, 10(1), 2018.

Rodrik, D. (1998). Essays in international finance: Vol. 55-65. Who needs capital-account convertibility? Academic Press.

Sulimierska, M. (2008). The Theoretical Link between Capital Account Liberalization and Currency Crisis Episodes. In International Trade and Finance Association Conference Papers (p. 15). bepress. 
Stiglitz, J. E. (2000). Capital Market Liberalization, Economic Growth and Instability. World Development, 22(6), 1075-1086. doi:10.1016/S0305-750X(00)00006-1

Verikios, G. (2018). Capital Account Liberalisation by China and the Effects on Global FDI and Trade. Global Economic Review, 47(3), 245-269. doi:10.1080/1226508X.2018.1436459

World Bank. (1999). Global economic prospects and the developing countries 1999/2000. World Bank.

World Bank. (n.d.). World Development Indicators. Retrieved from https://data.worldbank.org/

Badar Alam Iqbal is Emeritus Professor at International University of Business Agriculture and Technology, Bangladesh. He is also Chairman to the Institute FBIAR (Ghana). He has been Fulbright Fellow (SIR-2004, SIR-2017) for two times and has been the awardee of DAAD and Ford Fellowship. Presently he is also serving as Faculty of Economics and Finance, Monarch University, Zug (Switzerland). He is also Former, Extraordinary Professor of School of Economics and Finance, North-West University (Vaal) Campus, South Africa.

Nida Rahman is a PhD in Economics from Aligarh Muslim University. She works in the area of International Economics.

Mohd Nayyer Rahman is working as an Assistant Professor (Contractual) in the Department of Commerce, AMU. His area of research is International Economics, International Business and Applied Econometrics. He is Associate Editor of Journal of Advances in Management Sciences \& Information Systems, Ontario, Canada. He has represented India as a Young Researcher on BRICS Studies for two consecutive years (2018 \& 2019) in BRICS International School hosted by Russian Federation under the grant of Gorbochov Foundation. He has also participated in BRICS Forum on Economic Integration under BRICS 2020. His research publications have covered empirical evidences on BRICS studies, causality relationship of macroeconomic variables and Latin American countries, to name a few. His Scientific Membership includes UNCTAD Virtual Institute, United Nations; The Econometrics Society, USA; Chinese Economist Society, China and European Economic Association, European Association. Before joining the Department he was ICSSR-Postdoctoral Fellow and served as Assistant Professor, Department of Management, Integral University. His thesis has already been published under the title Impact of FDI Inflows on India's Balance of Payments: An Applied Time Series Econometrics Approach. His interest includes Reading, Public Speaking and Business Consulting. He has played professional Basketball for several clubs as well. He is also an amateur boxer with orthodox style. 